\title{
FAKTOR-FAKTOR YANG BERHUBUNGAN DENGAN KEJADIAN PNEUMONIA PADA BALITA
}

\author{
Riani Dwi Indah Sari, Lela Hartini, Mariati \\ Politeknik Kesehatan Kementerian Kesehatan Bengkulu, Jurusan Kebidanan, \\ Jalan Indragiri Nomor 03 Padang Harapan Kota Bengkulu \\ indahdwi1504@gmail.com
}

\begin{abstract}
Pneumonia is one of the causes of infant mortality. The percentage of pneumonia in Indonesia in 2009 increased (49.23\%) and in 2010, falling to (39.38\%) of the number of infants in Indonesia. In as many as 16.401 cases of Bengkulu province. The high incidence of pneumonia were found in 214 cases Curup health center. The purpose of this study determine the relationship of the factors associated with the incidence of pneumonia in infants Curup Work Area Health Center in 2013. This study used a case-control method with a number of 38 samples were taken in total control sampling and 38 samples were taken by simple random sampling. The place and time of the study, in Curup Health Center in January 2014. Retrieval of data using a data collection sheet was analyzed using Chi-square. Univariate analysis showed almost all of the infants $(89.5 \%)$ did not LBW, most of the infants $(65.8 \%)$ had complete immunization status and most of the infants (68.4\%) were exclusively breastfed. In bivariate analysis showed that risk factors have a relationship with the pneumonia is exclusive breastfeeding $(\mathrm{OR}=3.714)$, immunization status $(\mathrm{OR}=3.375)$ and the risk factors associated with pneumonia is not $\mathrm{LBW}(\mathrm{OR}=0.521)$.
\end{abstract}

Keyword: Low Baby Weight, immunization status, exclusive breastfeeding, pneumonia

\begin{abstract}
Abstrak: Pneumonia merupakan salah satu penyebab kematian balita. Persentase pneumonia di Indonesia pada tahun 2009 meningkat $(49,23 \%)$ dan tahun 2010 menurun mencapai $(39,38 \%)$ dari jumlah balita di Indonesia. Di Provinsi Bengkulu sebanyak 16.401 kasus. Masih tingginya angka kejadian pneumonia yang terdapat di Puskesmas Curup 214 kasus. Tujuan penelitian ini mengetahui hubungan faktor-faktor yang berhubungan dengan kejadian pneumonia pada balita di Wilayah kerja Puskesmas Curup Tahun 2013. Penelitian ini menggunakan metode case control dengan jumlah kasus 38 sampel diambil secara total sampling dan control 38 sampel diambil secara simple random sampling. Tempat dan waktu penelitian, di Puskesmas Curup pada Januari 2014. Pengambilan data menggunakan lembar pengumpulan data dianalisa menggunakan Chi-square. Analisis univariat menunjukkan hampir seluruh dari balita $(89,5 \%)$ tidak BBLR, sebagian besar dari balita $(65,8 \%)$ memiliki status imunisasi lengkap dan sebagian besar dari balita $(68,4 \%)$ mendapatkan ASI eksklusif. Pada analisis bivariat menunjukkan faktor risiko yang mempunyai hubungan dengan pneumonia adalah ASI eksklusif $(\mathrm{OR}=3,714)$, status imunisasi $(\mathrm{OR}=3,375)$ dan faktor risiko tidak berhubungan dengan pneumonia adalah $\operatorname{BBLR}(\mathrm{OR}=0,521)$.
\end{abstract}

Kata Kunci: BBLR, Status Imunisasi, ASI Eksklusif, Pneumonia

Salah satu indikator dalam mengukur keberhasilan pembangunan kesehatan suatu Negara dapat dilihat dari angka kematian ibu (AKI) dan angka kematian balita (AKB). Menurut Survei Demografi Kependudukan Indonesia (SDKI) AKI di Indonesia yaitu 228/100.000 Kelahiran Hidup (KH) dan AKB yaitu 34/1.000 KH sedangkan sesuai kesepakatan Millenium Development Goals (MDGs) target AKI menjadi 102/100.000 KH dan AKB menjadi 23/1.000 KH pada tahun 2015.
(SDKI, 2007). Kematian balita umumnya disebabkan oleh pneumonia, diare, malaria, dan campak (Depkes, 2010).

Berdasarkan data Health Statistic pneumonia merupakan penyebab kematian nomor 6 di Indonesia, nomor 9 di Brunei, nomor 7 di Malaysia, nomor 3 di Singapura, nomor 6 di Thailand dan nomor 3 di Vietnam. Di Indonesia berdasarkan hasil Riset Kesehatan Dasar (Riskesdas) tahun 2007, menunjukkan prevalensi nasional ISPA $(25,5 \%)$, angka 
morbiditas pneumonia pada bayi $(2,2 \%)$ dan balita (3\%), angka mortalitas pada bayi $(23,8 \%)$ dan balita $(15,5 \%)$ (Suripto, 2003). Persentase pneumonia di Indonesia tahun 2008 meningkat hingga $(49,45 \%)$. Tahun $2009(49,23 \%)$ dan tahun 2010 menurun hingga $(39,38 \%)$ dari jumlah balita di Indonesia (Kemenkes RI, 2010).

Angka kematian bayi per 1000 kelahiran hidup di Provinsi Bengkulu pada 4 tahun terakhir mengalami naik turun dimana pada tahun 200910,22 per $1000 \mathrm{KH}$, tahun 2010 menurun menjadi 5,2 per $1000 \mathrm{KH}$, tahun 2011 meningkat menjadi 9,6 per $1000 \mathrm{KH}$ dan terus meningkat pada tahun 2012 menjadi 10,7 per $1000 \mathrm{KH}$, adapun penyebab utama kematian bayi antara lain adalah pneumonia. Sedangkan angka kematian balita di Provinsi Bengkulu tahun 2012 meningkat menjadi 11,8 per 1000 kelahiran hidup dari 8,5 per 1000 kelhiran hidup pada tahun 2011 (Profil Dinkes Provinsi Bengkulu tahun 2012).

Menurut Greenberg (2005), faktor risiko yang berhubungan dengan kejadian pneumonia terbagi dua kelompok besar yaitu faktor instrinsik (umur, jenis kelamin, status gizi, Berat Badan Lahir Rendah (BBLR), status imunisasi, pemberian Air Susu Ibu (ASI), dan pemberian vitamin A dan faktor ekstrinsik (kepadatan tempat tinggal, tipe rumah, ventilasi, jenis lantai, kepadatan hunian, jenis bahan bakar, penghasilan keluarga serta faktor ibu baik pendidikan, umur, maupun pengetahuan dan keberadaan keluarga yang merokok). Menurut Fanada (2012), ada hubungan pendidikan tinggi, status imunisasi lengkap, ASI eksklusif, dan status gizi normal terhadap kejadian pneumonia pada balita. Karena keterbatasan peneliti, peneliti melakukan penelitian menggunakan tiga variabel yaitu BBLR, status imunisasi, dan ASI eksklusif.

BBLR merupakan sebutan bayi baru lahir yang berat badan lahirnya kurang dari 2.500 gram (Hassan, 2000). Pada bayi BBLR, pembentukan zat anti kekebalan kurang sempurna sehingga lebih mudah terkena penyakit infeksi terutama pneumonia dan sakit saluran pernapasan bagian bawah. Teori ini ditunjang oleh penelitian Rahmin (2011) yang mengatakan ada hubungan BBLR dengan kejadian pneumonia.

Imunisasi merupakan usaha memberikan kekebalan pada bayi dan anak dengan memasukan vaksin kedalam tubuh yang membuat zat kekebalan untuk mencegah terhadap penyakit tertentu (Hidayat, 2011). Teori ini ditunjang oleh penelitian Fanada (2012) yang mengatakan ada hubungan status imunisasi dengan kejadian pneumonia.

ASI eksklusif adalah pemberian ASI kepada bayi umur 0-6 bulan tanpa diberikan makanan atau minuman tambahan selain obat untuk terapi (WHO, 2001). ASI mengandung karbohidrat, protein, lemak, dan zat protektif dalam jumlah yang memadai yang mendapatkan ASI akan tumbuh secara optimal sehingga mengalami pertumbuhan berat badan ideal dan jarang menderita sakit. Teori ini ditunjang oleh penelitian Fanada (2012) yang mengatakan ada hubungan ASI eksklusif dengan kejadian pneumonia.

Angka kejadian pneumonia di Provinsi Bengkulu pada tahun 2012 sebanyak 16.401 perkiraan penderita pada anak balita dan hanya $1.043(6 \%)$ penderita ditemukan dan ditangani (Profil Dinkes Provinsi Bengkulu tahun 2012). Kejadian paling tinggi terdapat di Kabupaten Bengkulu Selatan yaitu 379 kasus (26\%) dan di kabupaten Rejang Lebong 241 kasus (11\%) yaitu tertinggi nomor dua. Angka kejadian pneumonia di beberapa Puskesmas Kabupaten Rejang Lebong Puskesmas Curup memilki kejadian pneumonia paling tinggi dengan jumlah kasus 214 (Profil Dinkes Kabupaten Rejang Lebong 2012).

Berdasarkan survei awal yang dilakukan pada 10 balita pada 15 Oktober 2013 sampai dengan 22 Oktober 2013, yang menderita pneumonia berjumlah 5 balita, 3 balita memiliki status imunisasi tidak lengkap, 2 balita tidak diberikan ASI eksklusif, 2 balita BBLR. Pada 5 balita yang tidak menderita pneumonia 2 balita memiliki status imunisasi tidak lengkap, 1 balita tidak diberikan asi eksklusif, 1 balita BBLR. Tujuan penelitian ini mengetahui hubungan faktor-faktor yang berhubungan dengan kejadian pneumonia pada balita di Wilayah kerja Puskesmas Curup Tahun 2013. 


\section{BAHAN DAN CARA KERJA}

Penelitian ini menggunakan metode penelitian Survei Analitik dengan desain Case Control, yaitu suatu penelitian yang menyangkut bagaimana faktor resiko dipelajari dengan menggunakan pendekatan Retrospective. Populasi dalam penelitian ini adalah seluruh balita (12-24 bulan) yang berkunjung di Puskesmas Curup yang berjumlah 342 balita dengan jumlah kejadian pneumonia 38 balita. Sampel dalam penelitian ini menggunakan perbandingan 1:1 untuk kasus dan kontrol.

Sampel kasus adalah semua ibu yang mempunyai balita yang berkunjung ke Puskesmas terdiagnosa pneumonia sejumlah 38 dengan teknik total sampling yaitu balita (12-24 bulan) yang mengalami pneumonia di Puskesmas Curup Kabupaten Rejang Lebong Tahun 2012. Sampel kontrol adalah semua ibu yang membawa balita ( $12-24$ bulan) berobat ke Puskesmas yang tidak menderita pneumonia. Pengambilan sampel kontrol menggunakan simple random sampling yaitu pengambilan sampel secara acak tanpa memperhatikan strata yang ada dalam anggota populasi, $342-38=304, \quad 304: 38=8$ sehingga semua kelipatan 8 diambil sampai berjumlah 38 sampel. Jadi jumlah sampel adalah $\mathrm{n} 1+\mathrm{n} 2=76$.

Analisa yang digunakan untuk menggambarkan distribusi frekuensi masing-masing dari variabel penelitian. Analisis bivariat dilakukan untuk mengetahui hubungan BBLR, status imunisasi, dan ASI eksklusif dengan kejadian pneumonia menggunakan uji ChiSquare yaitu mencari hubungan antara BBLR, status imunisasi, dan ASI eksklusif dengan kejadian pneumonia di wilayah Puskesmas Curup.

\section{HASIL}

Berdasarkan tabel 1 menunjukkan distribusi subyek penelitian pada kelompok kasus dan kontrol berdasarkan BBLR, status imunisasi, dan ASI eksklusif, dari 76 balita menunjukkan hampir seluruh dari balita $(85,5 \%)$ tidak BBLR, sebagian besar dari balita $(65,8 \%)$ mendapatkan imunisasi lengkap dan sebagian besar dari balita $(52,6 \%)$ tidak mendapatkan ASI secara eksklusif.

Tabel 1. Distribusi Frekuensi BBLR, Status Imunisasi, ASI Eksklusif

\begin{tabular}{lcccc}
\hline Variabel & $\begin{array}{c}\text { Kasus } \\
\text { (Pneumonia) } \\
\mathbf{n = 3 8}\end{array}$ & $\begin{array}{c}\text { Kontrol } \\
\text { (Tidak } \\
\text { Pneumonia) } \\
\mathbf{n = 3 8}\end{array}$ & $\mathbf{N = 7 6}$ & $\%$ \\
\hline BBLR & $(10,5 \%)$ & $7(18,4 \%)$ & 11 & 14,5 \\
Ya & $34(89,5 \%)$ & $31(81,6 \%)$ & 65 & 85,5 \\
Tidak & & & & \\
Status & & & & \\
Imunisasi & & & & \\
Tidak & $18(47,4 \%)$ & $8(21,1 \%)$ & 26 & 34,2 \\
Lengkap & $20(52,6 \%)$ & $30(78,9 \%)$ & 50 & 65,8 \\
Lengkap & & & & \\
ASI & & & & \\
Eksklusif & & & & \\
Tidak & $26(68,4 \%)$ & $14(36,8 \%)$ & 40 & 52,6 \\
$\begin{array}{l}\text { Eksklusif } \\
\text { Eksklusif }\end{array}$ & $12(31,6 \%)$ & $24(63,2 \%)$ & 36 & 47,4 \\
\hline
\end{tabular}

Berdasarkan tabel 2 dari 38 balita yang mengalami pneumonia hampir seluruh dari responden $(89,5 \%)$ tidak BBLR dan dari 38 balita yang tidak mengalami pneumonia hampir dari seluruh responden $(81,6 \%)$ tidak BBLR. Berdasarkan hasil analisa Chi Square $p=0,514>\alpha=0,05$ artinya Ho diterima, berarti tidak ada hubungan yang bermakna antara BBLR dengan kejadian pneumonia. OR $<1$ yaitu 0,521 berarti menunjukkan bahwa balita yang BBLR mempunyai risiko 0,5 kali untuk menderita pneumonia dari pada balita yang tidak BBLR.

Berdasarkan variabel status imunisasi dari 38 balita yang mengalami pneumonia dapat dilihat bahwa sebagian kecil dari responden $(47,4 \%)$ mendapat imunisasi tidak lengkap dan dari 38 balita yang tidak menderita pneumonia hampir seluruh dari responden $(78,9 \%)$ mendapat imunisasi lengkap. Ber-dasarkan hasil analisa ChiSquare didapatkan $p=0,030<\alpha=0,05$ artinya Ha diterima dan Ho ditolak, berarti adanya hubungan bermakna antara kelengkapan imunisasi dengan kejadian pneumonia. OR $>1$ yaitu 3,375 yang berarti menunjukkan balita yang status imunisasinya tidak lengkap memiliki risiko 3,3 kali untuk terkena penyakit pneumonia dibandingkan dengan balita yang status imunisasinya lengkap. 
130 Jurnal Media Kesehatan, Volume 9 Nomor 2, Oktober 2016, hlm 114-203

Tabel 2. Hubungan BBLR, Status Imunisasi, dan ASI Eksklusif Dengan Kejadian Pneumonia

\begin{tabular}{|c|c|c|c|c|c|c|c|c|}
\hline \multirow{2}{*}{ Variabel } & \multicolumn{2}{|c|}{$\begin{array}{c}\text { Pneumonia } \\
n=38\end{array}$} & \multicolumn{2}{|c|}{$\begin{array}{c}\text { Tidak Pneumonia } \\
n=38\end{array}$} & \multicolumn{2}{|c|}{ Total } & \multirow{2}{*}{$p$ Value } & \multirow{2}{*}{$\begin{array}{c}\text { OR } \\
(95 \% \mathrm{CI})\end{array}$} \\
\hline & $\mathbf{N}$ & $\%$ & $\mathbf{n}$ & $\%$ & $\mathbf{N}$ & $\%$ & & \\
\hline \multicolumn{9}{|l|}{ BBLR } \\
\hline $\mathrm{Ya}$ & 4 & 10,5 & 7 & 18,4 & 11 & 14,5 & \multirow[t]{2}{*}{0,514} & \multirow[t]{2}{*}{0,521} \\
\hline Tidak & 34 & 89,5 & 31 & 81,6 & 65 & 85,5 & & \\
\hline Status Imunisasi & 18 & 47,4 & 8 & 21,1 & 26 & 34,2 & \multirow[b]{2}{*}{0,030} & \multirow[b]{2}{*}{3,375} \\
\hline $\begin{array}{l}\text { Tidak Lengkap } \\
\text { Lengkap }\end{array}$ & 20 & 52,6 & 30 & 78,9 & 50 & 65,8 & & \\
\hline \multicolumn{9}{|l|}{ ASI Eksklusif } \\
\hline Tidak Eksklusif & 26 & 68,4 & 14 & 36,8 & 40 & 52,6 & \multirow[t]{2}{*}{0,012} & \multirow[t]{2}{*}{3,714} \\
\hline Eksklusif & 12 & 31,6 & 24 & 63,2 & 36 & 47,4 & & \\
\hline
\end{tabular}

Berdasarkan variabel ASI dari 38 balita yang mengalami pneumonia dapat dilihat bahwa sebagian besar dari responden $(68,4 \%)$ tidak mendapatkan ASI eksklusif dan dari 38 balita yang tidak mengalami pneumonia sebagian besar dari responden $(63,2 \%)$ mendapatkan ASI eksklusif. Berdasarkan analisa Chi Square didapatkan $p=0,012<\alpha=$ 0,05 yang artinya Ho ditolak, berarti ada hubungan antara pemberian ASI eksklusif dengan kejadian pneumonia. OR $>1$ yaitu 3,714 yang berarti menunjukkan ada hubungan penyakit pneumonia dengan paparan. Ini berarti balita yang tidak diberikan ASI eksklusif memiliki risiko 3,7 kali untuk terkena penyakit pneumonia dibandingkan dengan balita yang diberikan ASI eksklusif.

\section{PEMBAHASAN}

\section{Hubungan BBLR Dengan Kejadian Pneumonia Pada Balita}

Hasil penelitian menunjukkan dari 38 balita yang mengalami pneumonia hampir seluruh dari responden $(89,5 \%)$ tidak BBLR dan dari 38 balita yang tidak mengalami pneumonia hampir dari seluruh responden $(81,6 \%)$ tidak BBLR. Berdasarkan hasil analisa Chi Square $p=0,514>\alpha=0,05$ artinya Ho diterima, berarti tidak ada hubungan yang bermakna antara BBLR dengan kejadian pneumonia. $\mathrm{OR}<1$ yaitu 0,521 berarti menunjukkan bahwa balita yang BBLR mempunyai risiko 0,5 kali untuk menderita pneumonia dari pada balita yang tidak BBLR.

Penelitian ini sejalan dengan Regina (2013) yang mengatakan tidak adan hubungan BBLR dengan kejadian pneumonia dengan $\mathrm{p}=0,191>\alpha=0,05$. Hasil penelitian Regina
(2013) menunjukkan bahwa pneumonia juga dipengaruhi oleh faktor pemberian ASI eksklusif. Hal ini terjadi karena salah satu penyebabnya yaitu sampel dari penelitian hanya sedikit yaitu 1:1. Selain itu penelitian ini harusnya menggunakan metode prospektif.

Menurut Cissy (2007), tidak ada hubungan antara BBLR dengan kejadian pneumonia dapat dikarenakan nutrisi cukup yang didapatkan balita. Nutrisi yang cukup dapat membantu anak membangun dan memantapkan sistem kekebalan tubuh karena menyediakan energi dan protein dalam jumlah memadai untuk mendukung fungsi sistem kekebalan serta mengurangi insiden pneumonia.

Penelitian ini tidak sejalan dengan penelitian Rahmin (2011) yang mengatakan ada hubungan BBLR dengan kejadian pneumonia dengan nilai $R P=6,923$. Pada bayi dengan riwayat BBLR, pembentukan zat anti kekebalan kurang sempurna sehingga lebih mudah terkena penyakit infeksi terutama pneumonia karena belum berkembangnya sistem pertahanan tubuh dan pernapasannya sebaik anak yang lahir dengan berat badan cukup (Ani, 2011).

Hasil penelitian ini juga ditemukan hampir seluruh dari balita $(89,5 \%)$ tidak BBLR mengalami pneumonia dan sebagian kecil dari balita $(18,4 \%)$ BBLR tidak mengalami pneumonia. Pneumonia juga terjadi pada balita yang tidak BBLR karena banyak faktor yang mempengaruhi yaitu status imunisasi, ASI eksklusif, dan lingkungan (Rasmalia, 2004). Selain itu faktor cuaca di Curup bisa mempengaruhi terjadinya pneumonia walaupun balita tidak BBLR. 


\section{Hubungan Status Imunisasi dengan Kejadian Pneumonia pada Balita}

Hasil penelitian dari 38 balita yang mengalami pneumonia dapat dilihat bahwa sebagian kecil dari responden $(47,4 \%)$ mendapat imunisasi tidak lengkap dan dari 38 balita yang tidak menderita pneumonia hampir seluruh dari responden $(78,9 \%)$ mendapat imunisasi lengkap. Berdasarkan hasil analisa Chi-Square didapatkan $p=0,030<\alpha=0,05$ artinya Ha diterima dan Ho ditolak, berarti adanya hubungan bermakna antara kelengkapan imunisasi dengan kejadian pneumonia. OR>1 yaitu 3,375 yang berarti menunjukkan balita yang status imunisasinya tidak lengkap memiliki risiko 3,3 kali untuk terkena penyakit pneumonia dibandingkan dengan balita yang status imunisasinya lengkap.

Hasil dari penelitian ini balita yang status imunisasinya tidak lengkap lebih banyak menderita pneumonia dari pada balita yang status imunisainya lengkap, ini karena kekebalan tubuh anak balita juga dipengaruhi status imunisasi, oleh karena itu imunisasi sangat penting karena peluang untuk terkena penyakit terutama pneumonia lebih kecil dibandingkan dengan anak yang status imunisainya tidak lengkap.

Penelitian ini tidak sejalan dengan penelitian Rachmawati (2013) yang menunjukkan bahwa tidak ada hubungan signifikan antara status imunisasi dengan kejadian pneumonia dengan $p=1,000 \quad(p>0,05)$. Hal tersebut dikarenakan hampir seluruh balita $(92,5 \%)$ dengan status imunisasi lengkap mengalami pneumonia.

WHO telah membentuk Gerakan Rencana Aksi Global (GAPP) untuk pencegahan dan pengendalian pneumonia. GAPP merekomendasikan tentang apa yang perlu dilakukan, tujuan spesifik, target berapa nyawa yang akan diselamatkan dengan mencatat pentingnya imunisasi dengan mempercepat adopsi vaksin terjangkau dan efektif, manajemen terpadu balita sakit (MTBS) di masyarakat, pemberian ASI eksKlusif selama enam bulan, perbaikan gizi dan pecegahan BBLR. Intervensi yang dianjurkan GAPP adalah melindungi anak dengan memperhatikan lingkungan, mencegah anakanak menjadi sakit karena pneumonia (WHO, 2010).

Hasil penelitian ini juga ditemukan sebagian besar dari balita $(52,6 \%)$ yang mendapatkan imunisasi lengkap mengalami pneumonia dan sebagian kecil dari balita $(21,1 \%)$ yang tidak mendapatkan imunisasi lengkap tidak mengalami pneumonia. Pneumonia juga terjadi pada balita yang memiliki status imunisasi lengkap karena banyak faktor yang mempengaruhi yaitu pemberian ASI eksklusif, dan lingkungan (Rasmalia, 2004).

\section{Hubungan Pemberian ASI Eksklusif dengan Kejadian Pneumonia pada Balita}

Hasil penelitian dari 38 balita yang mengalami pneumonia dapat dilihat bahwa sebagian besar dari responden $(68,4 \%)$ tidak mendapatkan ASI eksklusif dan dari 38 balita yang tidak mengalami pneumonia sebagian besar dari responden $(63,2 \%)$ mendapatkan ASI eksklusif. Berdasarkan analisa Chi Square didapatkan $p=0,012<\alpha=0,05$ yang artinya Ho ditolak, berarti ada hubungan antara pemberian ASI eksklusif dengan kejadian pneumonia. OR>1 yaitu 3,714 yang berarti menunjukkan ada hubungan penyakit pneumonia dengan paparan. Ini berarti balita yang tidak diberikan ASI eksklusif memiliki risiko 3,7 kali untuk terkena penyakit pneumonia dibandingkan dengan balita yang diberikan ASI eksklusif.

Penelitian ini sejalan dengan penelitian Fanada (2012) menunjukkan ada hubungan bermakna dengan pemberian ASI eksklusif yaitu $61,7 \%$ yang tidak diberikan ASI eksklusif menderita pneumonia. Hasil analisis diperoleh $\mathrm{OR}=5,184$ artinya bahwa balita yang tidak diberikan ASI eksklusif memiliki resiko 5,2 kali untuk terkena penyakit pneumonia dibandingkan dengan balita yang diberikan ASI eksklusif. Hal ini ditunjang oleh teori Kartasasmita "Pneumonia Pembunuh Balita (2010), faktor risiko yang meningkatkan kejadian beratnya penyakit dan kematian karena pneumonia yaitu pemberian ASI eksklusif (mengurangi risiko), BBLR 
(meningkatkan risiko), vaksinasi (mengurangi risiko).

Pneumonia dipengaruhi oleh pemberian ASI eksklusif. ASI mengandung karbohidrat, protein, lemak, dan zat protektif dalam jumlah yang memadai yang mendapatkan ASI akan tumbuh secara optimal akan mengalami pertumbuhan berat badan ideal dan jarang menderita sakit.

Hasil penelitian ini juga ditemukan sebagian kecil dari balita $(31,6 \%)$ yang mendapatkan ASI eksklusif mengalami pneumonia dan hampir sebagian dari balita $(36,8 \%)$ tidak mendapatkan ASI eksklusif tidak mengalami pneumonia. Pneumonia juga terjadi pada balita yang mendapatkan imunisasi lengkap karena banyak faktor yang mempengaruhi yaitu pemberian ASI eksklusif, status gizi kurang, suplementasi vitamin A, BBLR, vaksinasi, dan polusi udara terutama asap rokok (Cissy, 2010).

\section{DAFTAR RUJUKAN}

Aini 2008. Faktor Risiko Penyakit Pneumonia Pada Balita Di Wilayah Kerja Puskesmas Curup. Karya Tulis Ilmiah Poltekkes Kesmenkes Bengkulu.

Andraini. 2012. Hubungan Kepadatan Hunian dan Perokok Pasif Terhadap Kejadian Pneumonia. Karya Tulis Ilmiah Poltekkes Kemenkes Bengkulu.

Ardiansyah. 2012. Medikal Bedah. Diva Press. Jogjakarta.

Budiarto. 2003. Metodologi Penelitian Kedokteran. EGC. Jakarta

Depkes RI. 2008. Profil Kesehatan Nasional. Jakarta : Departemen Kesehatan RI.

Dinkes Provinsi Bengkulu. 2012. Profil Kesehatan Provinsi Bengkulu. Bengkulu.

Dinkes Kabupaten Rejang Lebong. 2012. Profil Kesehatan Kabupaten RejangLebong. Curup.

Fanada. 2012. Faktor-faktor Yang Berhubungan Dengan Kejadian Penyakit Pneumonia Pada Anak Balita Di Wilayah Kerja Puskesmas Kenten Palembang. Jurnal Penelitian.

Greenberg. 2005. Community Acquired Pneumonia In Children. Chang Gun Med.

Hassan. 2007. Ilmu Kesehatan Anak 3. Infomedika. Jakarta.

Hidayat. 2005. Ilmu Kesehatan Anak. Jakarta: Salemba Medika

Kartasasmita. 2010. Pneumonia Pembunuh Balita. Buletin Jendela Epidemiologi Volume 3.

\section{KESIMPULAN}

Hampir seluruh dari responden tidak BBLR. Sebagian besar dari responden memiliki status imunisasi lengkap. Sebagian besar dari responden mendapatkan ASI eksklusif. Tidak ada hubungan BBLR dengan kejadian pneumonia pada balita. Ada hubungan kelengkapan imunisasi dengan kejadian pneumonia pada balita. Ada hubungan pemberian ASI eksklusif dengan kejadian pneumonia pada balita di Wilayah Kerja Puskesmas Curup Tahun 2013.

Diharapkan bagi petugas kesehatan yang ada di Wilayah Kerja Puskesmas Curup hendaknya dapat meningkatkan penyuluhan dan memberikan informasi kepada masyarakat Puskesmas Curup tentang pentingnya ASI eksklusif dan imunisasi untuk mencegah terjadinya pneumonia terutama pada balita dengan BBLR dan pengobatan seoptimal mungkin bagi penderita pneumonia.

Mansjoer. 2002. Kapita Selekta Kedokteran. Aesculapius. FKUI. Jakarta

Marimbi. 2010. Tumbuh Kembang, Status Gizi, dan Imunisasi Dasar Pada Balita. Nuha Medika. Yogyakarta.

Markum, 2002, Imunisasi, FKUI, Jakarta

Ngastiyah. 2003. Perawatan Anak Sakit. EGC. Jakarta.

Notoatmodjo. 2002. Metode Penelitian Kesehatan. Rhineka Cipta. Jakarta.

Nursalam. 2003. Konsep dan Penerapan Metodologi Penelitian Ilmu keperawatan. Jakarta: Salemba Medika.

Priyanti. 2007. Gambaran penyakit dan Sikap Ibu Dalam Mencegah Penyakit Pneumonia Pada Balita di Desa Air Bening. Karya Tulis Ilmiah Poltekkes Kemenkes Bengkulu.

Puskesmas Curup. 2012. Laporan Tahunan Puskesmas Curup Tahun 2012. Curup Rejang lebong.

Rachmawati. 2013.Faktor Risiko yang Berhubungan dengan Kejadian Pneumonia Pada Balita umur 12-48 Bulan Di Wilayah Kerja Puskesmas Mijen Kota Semarang. Jurnal Penelitian.

Rahmin. (2011). Faktor-faktor Yang Berhubungan Dengan Kejadian Suspek Pneumonia Pada Anak Balita Di Wilayah Kota Payakumbuh. Jurnal Penelitian

Saryono (2010), Metodologi Penelitian Kebidanan DIII, DIV, S1 dan S2. Rhieneka Cipta. Jakarta.

Simbolon. 2012. Buku Ajar Biostatistik Dasar. Bengkulu. 
Suyono. 2001. Ilmu Penyakit Dalam. Balai Penerbit FKUI. Jakarta.

Yuliasari. 2009. Faktor Risiko Pneumonia Pada Bayi Umur (6-12 bulan) di Wilayah Kerja Puskesmas
Curup. Karya Tulis Ilmiah Poltekkes Kemenkes Bengkulu. 